INDEPENDENT JOURNAL OF MANAGEMENT \& PRODUCTION (IJM\&P)

http://www.ijmp.jor.br

v. 11, n. 6, September - October 2020

ISSN: 2236-269X

DOI: 10.14807/ijmp.v11i6.1146

\title{
RAMADAN EFFECT ON SECTORAL HERDING
}

Mohammad Kamel Elshqirat

School of management, Walden University, United States

E-mail: Mohammad.elshqirat@waldenu.edu

Submission: 10/18/2019

Accept: 11/6/2019

\section{ABSTRACT}

One variable that affects stocks prices in the financial markets is herding behavior. As the level of herding is not constant over time, its level may be different during some events. Herding may increase during religious events like Ramadan in the Muslim world causing volatility to increase and leading to unexplained stock prices. The purpose of this study was to test the effect of Ramadan on herding presence at market and sector levels. The study was based on the behavioral finance theory which considers mood and behavior of investors as variables that may affect the prices of stocks. The enquiry that the researcher tried to answer was whether the presence of herding in the market and sectors is affected by Ramadan. To achieve the study purpose, a quantitative study was conducted using daily data from Amman stock exchange for the period from 2000 to 2018. Collected data were analyzed using ordinary least squares (OLS) method. The Results of market-level analysis showed that market investors do not herd during and out of Ramadan. At sector-level, however, herding is absent during Ramadan and exists out of it in services and industrial sectors while it's absent in both times in the financial sector.

Keywords: Amman stock exchange, behavioral finance, herding, sectoral herding, Ramadan effect. 
DOI: 10.14807/ijmp.v11i6.1146

\section{INTRODUCTION}

Herding behavior represents one cause of anomalies in the financial markets as it affects the prices of stocks making it different than expected (CAKAN; BALAGYOZYAN, 2016). The problem is that herding varies over time (SHARMA et al., 2015) which means that it may be reported as absent in general while it exists in some periods. Investors may think that herding is absent in a specific market and then get shocked by its effects during some occasions. One event that may have a positive effect on the mood of investors in the Muslim world is the month of Ramadan (BIAŁKOWSKI et al., 2012).

Ramadan is a Muslim religious occasion during which Muslims stop eating, drinking, and enjoying some other doings from the early dawn till the sunset for one lunar month (SONJAYA; WAHYUDI, 2016). Positive mood, high social interaction, and high optimism during the holy month may lead investors to follow each other when taking investment decisions and thus, increase herding (GAVRIILIDIS et al., 2016).

Many studies were conducted to test the effect of Ramadan on stocks returns (KHAN et al., 2017; LAI; WINDAWATI, 2017; SHAH et al., 2017; WASIUZZAMAN; ALMUSEHEL, 2018) and on herding (GAVRIILIDIS et al., 2016; YOUSAF et al., 2018). These studies, however, were focused on studying the effect of Ramadan at market-level while in this study, additional analysis was carried out to test the effect of the month at sector-level.

The main objectives of this study were to examine the effect of Ramadan on the presence of herding in the Jordanian stock market at market-level and to determine whether this effect is different when tested at sector- level. To achieve these objectives, two hypotheses were developed. The first hypothesis was focused on testing whether the presence of herding at market-level is different during Ramadan than other times while the second hypothesis was to conduct the same test but at sector-level.

Determining whether herding behavior exists in Ramadan and whether it's more significant during the holy month may benefit investors by helping them determine the best investment strategy during the event. In addition, proving that herding during Ramadan is not the same at market-level and at sector- level may help researchers focus their efforts on studying herding and its causes at sector-level rather than depending on the misleading results that may be concluded when the behavior is studied at market- level only. 
DOI: 10.14807/ijmp.v11i6.1146

\section{LITERATURE REVIEW}

\subsection{Herding Behavior}

Investors are said to be herding when they invest in the same stocks at the same time either to follow their colleagues or to follow the market average (Indārs et al., 2019). Herding can be intentional or spurious (INDĀRS et al., 2019). Investors herd intentionally when they knowingly choose to copy the investment decisions of others (BIKHCHANDANI; SHARMA, 2000).

Spurious herding occurs when many investors adopt the same investment decisions not because they want to do so but because they face the same investment conditions and have the same information (BIKHCHANDANI; SHARMA, 2000); in this case, it appears like investors are herding but in fact they are doing it unintentionally.

As argued by Indārs et al. (2019), spurious herding is a rational behavior while intentional herding may be rational if it's based on information asymmetry or irrational if it's based on psychological factors like the need for security and safety. When herding exists in financial markets, investors simultaneously buy and sell the same stocks and thus, the prices of those stocks will change significantly causing market volatility to increase (BAKAR; YI, 2016). Furthermore, herding in financial markets may cause assets prices to deviate from its fundamental values estimated using the traditional asset pricing models including capital asset pricing model and the arbitrage pricing theory (CAKAN; BALAGYOZYAN, 2016).

To measure the presence of herding behavior, I utilized a measure introduced by Chang et al. (2000) who used a measure called the cross-sectional absolute deviation (CSAD). To measure the presence of herding, two steps should be followed: the first step is to calculate CSAD using the following equation (CHIANG et al., 2013):

$$
\operatorname{CSAD}_{t}=\frac{\sum_{i=1}^{N}\left|R_{i, t}-R_{m, t}\right|}{N}
$$

Where CSADt is the measure of stocks returns' dispersion on day t, Ri,t is the realized return for stock i on day t, Rm,t is the average of realized returns of all stocks on day t, and $\mathrm{N}$ is the total number of stocks on day t. the second step in measuring the existence of herding is to run the following regression model (CHANG et al., 2000):

$$
C S A D_{t}=\alpha+\lambda_{1}\left|R_{m i, t}\right|+\lambda_{2}\left(R_{m i, t}\right)^{2}+\varepsilon_{t}
$$


DOI: 10.14807/ijmp.v11i6.1146

Where CSADt is the returns' dispersion calculated in Equation1, Rmi,t is the realized return of market index on day t. If herding exists, $\lambda_{2}$ will have a significant negative value. These two steps can be used to test herding presence at market-level. The previous two equations, however, can be adjusted to test herding at sector-level as follows (ELSHQIRAT, 2019):

$C S A D_{s t}=\frac{\sum_{i=1}^{N}\left|R_{i, t}-R_{m s, t}\right|}{N}$

Where CSADst is the measure of stocks returns' dispersion in each sector on day t, Ri,t is the realized return for stock i on day $t, R m s, t$ is the average of realized returns of all stocks in the sector on day $\mathrm{t}$, and $\mathrm{N}$ is the total number of stocks in the sector on day $\mathrm{t}$

And

$C S A D_{s t}=\alpha+\lambda_{1}\left|R_{m i s, t}\right|+\lambda_{2}\left(R_{m i s, t}\right)^{2}+\varepsilon_{t}$

Where CSADst is the sectors returns' dispersion calculated in Equation 3 and Rmis,t is the realized return of sector index on day $\mathrm{t}$

Herding behavior was detected in many financial markets of many countries including the United States and United Kingdom (GALARIOTIS et al., 2015), Australia (AL-SHBOUL, 2012), China (MAHMUD; TINIÇ, 2018), Germany (KREMER; NAUTZ, 2013), Spain (ANDREU et al., 2015), Portugal (HOLMES et al., 2013), Turkey (AKINSOMI et al., 2018), Indonesia (CANDRANINGRAT, 2018), Mongolia (ERDENETSOGT; KALLINTERAKIS, 2016), Pakistan (QASIM et al., 2019), India (DUTTA et al., 2016), Romania (TRENCA et al., 2015), South Africa (NASARUDIN et al., 2017); Kwait and Qatar (DEMIR; SOLAKOGLU, 2016), Saudi Arabia (RAHMAN et al., 2015), Tunisia (HAMMAMI; BOUJELBENE, 2015), and Jordan (NASARUDIN et al., 2017; OBAIDAT, 2016; RAMADAN, 2015). Most of studies about herding behavior were conducted at market-level with few studies conducted at sectorlevel.

The level of herding effect depends on the specific characteristics of the sector and investors in that sector (BENSAÏDA, 2017). This difference was evidenced by Litimi et al. (2016) who concluded that the effect of herding behavior is different across sectors and Choi and Sias (2009) who claimed that investors in different sectors may have different level of herding. Herding behavior was concluded to be different in sectors of financial and technology industries (CAKAN; BALAGYOZYAN, 2016) and in properties and industrial sectors (SHARMA et al., 2015). 
DOI: 10.14807/ijmp.v11i6.1146

\subsection{Calendar Anomaly}

The efficiency of financial markets can be affected by some anomalies including calendar anomalies (KHAN et al., 2017). Calendar anomaly means that stocks' returns exhibit a specific pattern during a specific time of the day or of the month or the year like the first days of the year, holidays, weekends, some dates in Islamic calendar, and so on (MAJEED et al., 2015).

Calendar anomaly breaks the rules of the efficient market hypothesis (SALMAN IRAG AL-NAJAF et al., 2018) which states that there is no way to gain abnormal profit using available information because it's all reflected on the prices (ROSSI, 2015). Calendar anomaly, however, enables investors to predict prices during specific days which means that prices become a function of not only available information but also calendar effect.

According to Sonjaya and Wahyudi (2016), calendar anomalies can be religious-related or non- religious-related. Non-religious-related calendar anomalies include January effect, dayof-the-week-effect, and turn-of-the-month effect (ROSSI, 2015). Religious-related anomalies are those occurring during religious occasions including Christmas and good Friday for Christians, Rosh Hashanah and Yom Kippur for Jewish, and Ramadan for Muslims.

Calendar effect in financial markets was studied by many researchers including Seif et al. (2017) who found evidence of anomalies of day-of-the-week and the month of the year, Easterday and Sen (2016) and Norvaisiene et al. (2015) whose conclusions supported the existence of January effect, Dicle and Levendis (2014) who concluded that the Day-of-theweek effect exists in 51 equity markets, and Sharma and Narayan (2014) who evidenced the turn-of-the-month effect on returns and volatility. Marrett and Worthington (2009) examined the effect of Christmas and Easter holidays on the Australian stock market and concluded that there was a pre-holiday effect. Jewish holidays were concluded to affect stocks returns in the United States stock market (MEHRAN et al., 2012) and in Israeli market (KAPLANSKI; LEVY, 2012).

The effect of Islamic calendar anomalies on stock markets were evidenced by Majeed et al. (2015) who studied the effect of many Islamic events including the month of Ramadan and concluded that these events do affect stock returns in the Pakistani market. The most examined anomaly related to the Islamic calendar is the effect of Ramadan month (IRSHAD; TAIB, 2017). Ramadan may affect financial markets because it affects the entire environment of some Muslim countries (KHAN et al., 2017). In many Islamic countries, however, stock 
DOI: 10.14807/ijmp.v11i6.1146

prices are higher and its volatility is lower in Ramadan comparing to other months of the year (BIAŁKOWSKI et al., 2012).

\subsection{Herding in Ramadan}

Ramadan is a sacred month for Muslims in which they refrain from eating, drinking, and having sex during the day (YOUSAF et al., 2018). During Ramadan, Muslims have a very typical daily life in which they experience lower level of nervousness and high level of social communication. As a part of their communities, investors in the financial markets have the same low level of nervousness, life similarity, and strong social communication during Ramadan which may cause them to follow the investment decisions of each other (YOUSAF et al., 2018).

Herding during Ramadan, however, may be Spurious not intentional as it occurs because of the same feelings experienced by investors during Ramadan (Gavriilidis et al., 2016). In addition, good mood of investors during Ramadan reduces their tendency to analyze information when taking their investment decisions (AL-HAJIEH et al., 2011) which may explain their herding behavior during the holy month. Based on this, herding behavior may exist in Ramadan even if it does not exist in other months of the year.

Herding behavior was concluded to be stronger in Ramadan (GAVRIILIDIS et al., 2016) due to the positive mood of investors during the month though it was reported absent by other researchers (YOUSAF et al., 2018). Although investing in some listed companies is prohibited in Islam (e.g. traditional banks and insurance companies), Muslim investors continue to be active in the market even during the holy month of Ramadan.

Because Jordan is an Islamic country where the vast majority of people are Muslims, Ramadan is anticipated to affect the behavior of investors including their tendency to herd because of the strong social interaction and the avoidance of information analysis. If herding is different across sectors as claimed by many studies (BENSAÏDA, 2017; CAKAN; BALAGYOZYAN, 2016; CHOI; SIAS, 2009; LITIMI et al., 2016; SHARMA et al., 2015), the way it's affected by Ramadan can be hypothesized to be also different. No studies were conducted to explore the effect of Ramadan on the herding behavior in the Jordanian stock market and thus, value added by this study may be twofold: be among first studies to test Ramadan effect on herding in the Jordanian stock market and be the first study to examine that effect at sector-level. 
DOI: 10.14807/ijmp.v11i6.1146

\subsection{Hypotheses}

The purpose of this study was to examine the effect of Ramadan on the presence of Herding behavior in the Jordanian financial market. To achieve this purpose, two hypotheses were developed; the first hypothesis was to examine Ramadan affect on the presence of herding at market-level while the second hypothesis was to test Ramadan effect at sector-level. The two hypotheses of the study were as follows:

- H1: Herding presence is different in Ramadan than in other months of the year when tested at market-level

- H2: Herding presence is different in Ramadan than in other months of the year when tested at sector-level

\section{METHOD}

\section{1. $\quad$ Research Data}

All listed companies in Amman stock exchange (ASE) were included in this study; these companies are divided into three sectors: financial sector, services sector, and industrial sector. Study data consist of the daily closing prices for the included stocks and for the market index during the period from January 1, 2000 to December 31, 2018. Market index used was the ASE free float index because it's the only index among three other indices that is not biased to large-cap companies.

Daily closing prices for the listed stocks and for the index were downloaded from the ASE website. After downloading data, study variables were calculated and filtered to isolate values related to Ramadan month from that of other months. As Ramadan month depends on the lunar calendar and not on the Gregorian calendar, its time is not fixed across years and needs to be determined yearly by observing its crescent moon at a specific time. To determine Ramadan date for each calendar year included in the study, I used a website called timeanddate (TIME AND DATE, 2019) which provides dates of Ramadan for each year. Collected data were analyzed using the ordinary least squares which was used by Chang et al. (2000).

\subsection{Research Design}

Following many previous studies, quantitative approach was used in this study to test the effect of Ramadan on the presence of herding behavior in the Jordanian stock market at market-level and at sector-level. This purpose was achieved by examining the relationship 
DOI: 10.14807/ijmp.v11i6.1146

between the cross-sectional absolute deviation (CSAD) as a dependent variable and the independent variables of the absolute value and squared value of the market/sector index return

\subsection{Variables Definitions}

Average realized return on stocks in the market $(\mathrm{Rm}, \mathrm{t})$ : is the average return on all available stocks in the market on day t. This is the simple average of returns on all stocks available on each specific day.

Average realized return on stocks in the sector $(\mathrm{Rms}, \mathrm{t})$ : this variable is the simple average of returns on stocks available in the sector on day $\mathrm{t}$.

Cross-sectional absolute deviation for the market (CSADt): is a measure of the dispersion of stocks' returns in the market. This measure is calculated as follows (CHIANG et al., 2013):

$$
C S A D_{t}=\frac{\sum_{i=1}^{N}\left|R_{i, t}-R_{m, t}\right|}{N}
$$

Where CSADt is the measure of stocks returns' dispersion in the market on day t, Ri,t is the realized return for stock $\mathrm{i}$ on day $\mathrm{t}, \mathrm{Rm}, \mathrm{t}$ is the average of realized returns on all stocks in the market on day $\mathrm{t}$, and $\mathrm{N}$ is the total number of stocks in the market on day $\mathrm{t}$.

Cross-sectional absolute deviation for each sector (CSADst): is a measure of the dispersion of stocks returns in each sector. This variable was measured as follows (ELSHQIRAT, 2019):

$C S A D_{s t}=\frac{\sum_{i=1}^{N}\left|R_{i, t}-R_{m s, t}\right|}{N}$

Where CSADst is the measure of stocks returns' dispersion in each sector on day t, Ri,t is the realized return for stock $\mathrm{i}$ on day $\mathrm{t}, \mathrm{Rms}, \mathrm{t}$ is the average of realized returns on all stocks in each sector on day $\mathrm{t}$, and $\mathrm{N}$ is the total number of stocks in each sector on day $\mathrm{t}$.

Realized return of stock $(\mathrm{Ri}, \mathrm{t})$ : is realized return on stock i on day t calculated as follows:

$R_{i, t}=\left[\frac{P_{i, t}-P_{i, t-1}}{P_{i, t-1}}\right] * 100$

Where Pi,t is the closing price of the stock $\mathrm{i}$ on day $\mathrm{t}$ and Pi,t-1is the closing price of that stock on the day before. 
DOI: 10.14807/ijmp.v11i6.1146

Realized return on the market index $(\mathrm{Rmi}, \mathrm{t})$ : is the return on the market free float index on day t. this return was calculated using the following equation:

$R_{m i, t}=\left[\frac{P_{m i, t}-P_{m i, t-1}}{P_{m i, t-1}}\right] * 100$

Where Pmi,t is the closing price of ASE index on day t and Pmi,t-1is the closing price of the index on the previous day.

Realized return on the sector's index (Rmis,t): this is the return on the sector's index calculated as follows:

$$
R_{m i s, t}=\left[\frac{P_{m i s, t}-P_{m i s, t-1}}{P_{m i s, t-1}}\right] * 100
$$

Where Pmis,t is the closing price of the sector's index on day t and Pmis,t-1is the closing price of that index on the previous day.

\section{RESULTS}

\subsection{Descriptive Statistics}

As on December 31st, 2018, the total number of listed companies in ASE was 191 companies. About 51\% of these companies (98 companies) operate in the financial sector, $24 \%$ (46 companies) operate in services sector, and the remaining companies (47 companies) are operating in industrial sector. Descriptive information about CSAD, market index, and sectors indices for the period covered in the study are summarized in Table 1.

Table 1: Descriptive Statistics about: CSADt (Market CSAD), CSAD for Sectors, Return on Market Index, and Return on Sectors' Indices

\begin{tabular}{|l|c|c|c|c|}
\hline \multicolumn{1}{|c|}{ Details } & Mean & Standard deviation & Min & Max \\
\hline CSAD $_{\mathrm{t}}$ & 1.217 & 0.500 & 0.000 & 17.345 \\
\hline CSAD financial sector & 1.183 & 1.029 & 0.000 & 60.218 \\
\hline CSAD services sector & 1.262 & 0.691 & 0.000 & 16.388 \\
\hline CSAD industrial sector & 1.179 & 0.794 & 0.000 & 44.937 \\
\hline Return on market index \% & 0.013 & 0.823 & -4.425 & 4.797 \\
\hline $\begin{array}{l}\text { Return on financial sector } \\
\text { index \% }\end{array}$ & 0.020 & 0.851 & -4.651 & 5.392 \\
\hline $\begin{array}{l}\text { Return on services sector } \\
\text { index \% }\end{array}$ & 0.005 & 0.815 & -3.818 & 4.403 \\
\hline $\begin{array}{l}\text { Return on industrial sector } \\
\text { index \% }\end{array}$ & 0.015 & 1.091 & -17.084 & 20.079 \\
\hline
\end{tabular}


ISSN: 2236-269X

DOI: 10.14807/ijmp.v11i6.1146

\subsection{Hypotheses Testing}

\subsubsection{Hypothesis One}

The first hypothesis was about the effect of Ramadan on the presence of herding at market-level. To test this hypothesis, the following model was used:

$\operatorname{CSAD}_{t}=\alpha+\lambda_{1}\left|R_{m i, t}\right|+\lambda_{2}\left(R_{m i, t}\right)^{2}+\varepsilon_{t}$

Where CSADt is the returns' dispersion calculated in Equation 1and Rmi,t is the realized return of market index on day t. A significant and negative value for $\lambda 2$ means that herding exists at market level. The model was used to test herding presence during and out of Ramadan. The null hypothesis was that the existence of herding behavior in the Jordanian stock market is the same during Ramadan and during other months while the alternate hypothesis was that the presence of the behavior is different in Ramadan than in other months.

Depending on the regression results summarized in Table 2 and using a significance level of 5\%, it can be concluded that herding does not exist at market-level in Ramadan $\lambda_{2}=$ 0.024, $p=.421$ and in other months $\lambda_{2}=-0.016, p=.074$. This means that the presence of herding in Ramadan and non-Ramdan periods is the same because it was absent in both periods and thus, the null hypotheis cannot be rejected.

Table 2: Regression Analysis Results for Hypothesis One

\begin{tabular}{|c|c|c|c|}
\hline Details & Value & $t$ statistic & $P$ value \\
\hline \hline \multicolumn{4}{|c|}{ Ramadan month } \\
\hline \hline$\lambda_{1}$ & 0.906 & 34.104 & .000 \\
\hline$\lambda_{2}$ & 0.423 & 5.882 & .000 \\
\hline Adjusted R square & -0.024 & -0.805 & .421 \\
\hline \hline \multicolumn{4}{|c|}{ Other months } \\
\hline \hline$\alpha$ & .286 & 87.297 & .000 \\
\hline$\lambda_{1}$ & 1.004 & 16.303 & .000 \\
\hline$\lambda_{2}$ & 0.426 & -1.784 & .074 \\
\hline Adjusted R square & -0.016 & & \\
\hline
\end{tabular}

\subsubsection{Hypothesis Two}

The second hypothesis was developed to test the effect of Ramadan on the presence of herding at sector-level. The model used for this hypothesis was:

$C S A D_{s t}=\alpha+\lambda_{1}\left|R_{m i s, t}\right|+\lambda_{2}\left(R_{m i s, t}\right)^{2}+\varepsilon_{t}$

Where CSADst is the sector's returns' dispersion calculated in Equation 3and Rmis,t is the realized return of sector index on day t. The same rule about $\lambda 2$ applies here: if it has a 
INDEPENDENT JOURNAL OF MANAGEMENT \& PRODUCTION (IJM\&P)

http://www.ijmp.jor.br

v. 11, n. 6, September - October 2020

ISSN: 2236-269X

DOI: 10.14807/ijmp.v11i6.1146

negative and significant value then herding exists in the sector and vice versa. The model in Equation 11 was used to test the existence of herding in each sector during and out of Ramadan. The null hypothesis was that the presence of herding is the same during Ramadan and out of it when tested at sector-level while the alternate hypothesis was that the presence of the behavior is different in Ramadan than in other months.

Based on the regression results showed in Table 3 and using the same significance level in hypothesis 1 , the null hypothesis for the financial sector cannot be rejected because herding was absent during Ramadan $\lambda_{2}=-0.016, \mathrm{p}=.693$ and during other months $\lambda_{2}=-0.022, \mathrm{p}=$ .244. For services sector, however, the null hypothesis can be rejected because investors in this sector did not exihbit herding in Ramadan $\lambda_{2}=0.009, \mathrm{p}=.824$ but they herded in other months $\lambda_{2}=-0.037, \mathrm{p}=.013$. Finally, herding did not exist in the industrial sector during Ramadan $\lambda_{2}$ $=0.037, \mathrm{p}=.060$ but it existed in other months $\lambda_{2}=-0.013, \mathrm{p}<.001$ which means that the null hypothesis can be rejected. These results indicate that herding presence in services and industrial sectors is different in Ramadan than in other months.

Table 3: Regression Analysis Results for Hypothesis Two

\begin{tabular}{|c|c|c|c|}
\hline Details & Value & $t$ statistic & $P$ value \\
\hline \multicolumn{4}{|c|}{ Financial sector: Ramadan month } \\
\hline$\alpha$ & 0.900 & 26.156 & .000 \\
\hline$\lambda_{1}$ & 0.361 & 3.968 & .000 \\
\hline$\lambda_{2}$ & -0.016 & -0.394 & .693 \\
\hline Adjusted R square & .157 & & \\
\hline \multicolumn{4}{|c|}{ Financial sector: other months } \\
\hline$\alpha$ & 0.976 & 37.165 & .000 \\
\hline$\lambda_{1}$ & 0.414 & 7.115 & .000 \\
\hline$\lambda_{2}$ & -0.022 & -1.165 & .244 \\
\hline Adjusted R square & .046 & & \\
\hline \multicolumn{4}{|c|}{ "Services sector: Ramadan month } \\
\hline$\alpha$ & 1.004 & 25.382 & .000 \\
\hline$\lambda_{1}$ & 0.292 & 2.780 & .006 \\
\hline$\lambda_{2}$ & 0.009 & 0.223 & .824 \\
\hline Adjusted R square & .116 & & \\
\hline \multicolumn{4}{|c|}{ Services sector: other months } \\
\hline$\alpha$ & 1.033 & 59.533 & .000 \\
\hline$\lambda_{1}$ & 0.482 & 11.588 & .000 \\
\hline$\lambda_{2}$ & -0.037 & -2.483 & .013 \\
\hline Adjusted R square & .114 & & \\
\hline \multicolumn{4}{|c|}{ industrial sector: Ramadan month } \\
\hline$\alpha$ & 0.928 & 35.031 & .000 \\
\hline$\lambda_{1}$ & 0.121 & 2.077 & .038 \\
\hline$\lambda_{2}$ & 0.037 & 1.885 & .060 \\
\hline Adjusted R square & .227 & & \\
\hline \multicolumn{4}{|c|}{ industrial sector: other months } \\
\hline
\end{tabular}


DOI: 10.14807/ijmp.v11i6.1146

\begin{tabular}{|c|c|c|c|}
\hline$\alpha$ & 1.026 & 58.041 & .000 \\
\hline$\lambda_{1}$ & 0.255 & 12.680 & .000 \\
\hline$\lambda_{2}$ & -0.013 & -5.998 & .000 \\
\hline Adjusted R square & .039 & & \\
\hline
\end{tabular}

\section{DISCUSSION}

Study results do not support the first hypothesis concerning the difference in herding during and out of Ramadan at market-level because it revealed that the behavior was absent in both times. This conclusion is the same reached by Yousaf et al. (2018) who found that herding behavior is not affected by Ramadan in Pakistani market and opposite to the results of Gavriilidis et al. (2016) who concluded that herding is more significant in Ramadan than outside of it in five Muslim countries (Bangladesh, Egypt, Indonesia, Morocco, and Turkey).

When testing Ramadan effect on herding at sector-level, results showed that investors in services and industrial sectors did not herd during Ramadan while they herded during other days of the year and investors in financial sector did not herd during and outside of Ramadan. Herding was expected to exist in Ramadan even if it's absent in other months. In this study, however, the opposite direction was detected, herding existed out of Ramadan and was absent during it. This conclusion needs more research to determine why investors herd in nonRamadan days and don't herd during Ramadan as expected in the theory.

Study results represent the Jordanian market and other similar markets because all listed companies in the market were included with no exceptions. The study may add value to literature as one of the few studies about the effect of Ramadan on herding and the first to study that effect at sector- level. Study results can help investors in the Jordanian market by providing them with an evidence for the absence of herding during Ramadan so they can consider this fact in their trading strategies.

In addition, knowing that herding behavior stops in Ramadan at sector-level may encourage researchers to study the reasons behind that absence and try to advise authorities to provide the same environment of Ramadan to other times of the year to stop herding behavior during these times. Future studies may be conducted to reveal why herding is different in Ramadan than other times in the services and industrial sectors while it's not different in the financial sector. 
DOI: 10.14807/ijmp.v11i6.1146

\section{REFERENCES}

AKINSOMI, O.; COSKUN, Y.; GUPTA, R. (2018) Analysis of herding in REITs of an emerging market: the case of Turkey. Journal of Real Estate Portfolio Management, v. 24, n. 1, p. 65-81. Available: https://aresjournals.org/loi/repm. Access: 20th June, 2019.

AL-HAJIEH, H.; REDHEAD, K.; RODGERS, T. (2011) Investor sentiment and calendar anomaly effects: A case study of the impact of Ramadan on Islamic Middle Eastern markets. Research in International Business and Finance, v. 25, n. 3, p. 345-356. DOI: 10.1016/j.ribaf.2011.03.004

AL-SHBOUL, M. (2012) Asymmetric effects and the herd behavior in the Australian equity market. International Journal of Business and Management, v. 7, n. 7, p. 121-140. DOI: 10.5539/ijbm.v7n7p121

ANDREU, L.; GARGALLO, P.; SALVADOR, M.; SARTO, J. L. (2015) Bayesian analysis of herding behaviour: an application to Spanish equity mutual funds. Applied Stochastic Models in Business and Industry, v. 31, n. 6, p. 745-761. DOI: 10.1002/asmb.2087

BAKAR, S.; YI, A. N. C. (2016) The impact of psychological factors on investors' decision making in Malaysian stock market: a case of Klang Valley and Pahang. Procedia Economics and Finance, v. 35, p. 319-328. DOI: 10.1016/S2212-5671(16)00040-X

BENSAÏDA, A. (2017) Herding effect on idiosyncratic volatility in US industries. Finance Research Letters, v. 23, p. 121-132. DOI: 10.1016/j.frl.2017.03.001

BIAŁKOWSKI, J.; ETEBARI, A.; WISNIEWSKI, T. P. (2012) Fast profits: Investor sentiment and stock returns during Ramadan. Journal of Banking \& Finance, v. 36, n. 3, p. 835-845. DOI: 10.1016/j.jbankfin.2011.09.014

BIKHCHANDANI, S.; SHARMA, S. (2000) Herd behavior in financial markets. IMF Staff papers, v. 47, n. 3, p. 279-310. DOI: 10.2139/ssrn.228343

CAKAN, E.; BALAGYOZYAN, A. (2016) Sectoral herding: Evidence from an emerging market. Journal of Accounting and Finance,v. 16, n. 4, p. 87-99. Available: http://www.nabusinesspress.com/jafopen.html. Access: 22th June, 2019.

CANDRANINGRAT, I. R. (2018) Analysis of herding behavior in the Indonesian capital stock market. In: 1st ACEH GLOBAL CONFERENCE, INDONESIA, 2018. DOI: 10.2991/agc-18.2019.59

CHANG, E. C.; CHENG, J. W.; KHORANA, A. (2000) An examination of herd behavior in equity markets: An international perspective. Journal of Banking \& Finance, v. 24. n. 10, p. 1651-1679. DOI: 10.1016/S0378-4266(99)00096-5

CHIANG, T. C.; LI, J.; TAN, L.; NELLING, E. (2013) Dynamic herding behavior in Pacific-Basin markets: Evidence and implications. Multinational Finance Journal, v. 17, n. 3/4, p. 165-200. DOI: $10.17578 / 17-3 / 4-3$

CHOI, N.; SIAS, R. W. (2009) Institutional industry herding. Journal of Financial Economics, v. 94, n. 3, p. 469-491. DOI: 10.1016/j.jfineco.2008.12.009

DEMIR, N.; SOLAKOGLU, M. N. (2016) Herding in middle eastern frontier markets: Are local and global factors important?, in P. ANDRIKOPOULOS, G. N. GREGORIOU, V. KALLINTERAKIS (Eds.), Handbook of frontier markets. Cambridge, MA: Academic Press, p. 3-17. 
DICLE, M. F.; LEVENDIS, J. D. (2014) The day-of-the-week effect revisited: international evidence. Journal of Economics and Finance, v. 38, n. 3, p. 407-437. DOI: 10.1007/s12197-011-9223-6

DUTTA, A.; GAHAN, P.; PANDA, S. K. (2016) Evidences of herding behaviour in the Indian stock market. Vilakshan: The XIMB Journal of Management, v. 13, n. 2, p. 23-40. Available: https://www.xub.edu.in/XUB-JOURNALS/xub-journals-Vilakshan.html. Access: 21th June, 2019.

EASTERDAY, K. E.; SEN, P. K. (2016) Is the January effect rational? Insights from the accounting valuation model. The quarterly review of economics and finance, v. 59, p. 168185. DOI: 10.1016/j.qref.2015.05.001

ELSHQIRAT, M. (2019) Testing sectoral herding in the Jordanian stock market. International Business Research, v. 12, n. 8, p. 88-106. DOI: 10.5539/ibr.v12n8p88

ERDENETSOGT, A.; KALLINTERAKIS, V. (2016) Investors' herding in frontier markets: Evidence from Mongolia, in P. ANDRIKOPOULOS, G. N. GREGORIOU, V. KALLINTERAKIS (Eds.), Handbook of Frontier Markets, p. 233-249. DOI: 10.1016/B978-0-12-803776-8.00012-4

GALARIOTIS, E. C.; RONG, W.; SPYROU, S. I. (2015) Herding on fundamental information: A comparative study. Journal of Banking \& Finance, v. 50, p. 589-598. DOI: 10.1016/j.jbankfin.2014.03.014

GAVRIILIDIS, K.; KALLINTERAKIS, V.; TSALAVOUTAS, I. (2016) Investor mood, herding and the Ramadan effect. Journal of Economic Behavior \& Organization, v. 132, p. 23-38. DOI: $10.1016 /$ j.jebo.2015.09.018

HAMMAMI, H.; BOUJELBENE, Y. (2015) Investor herding behavior and its effect on stock market boom-bust cycles. IUP Journal of Applied Finance, v. 21, n. 1, p. 38-53. Available: https://iupindia.in/Applied_Finance.asp. Access: 21th June, 2019.

HOLMES, P.; KALLINTERAKIS, V.; FERREIRA, M. L. (2013) Herding in a concentrated market: a question of intent. European Financial Management, v. 19, n. 3, p. 497-520.

DOI: 10.1111/j.1468-036X.2010.00592.X

INDĀRS, E. R.; SAVIN, A.; LUBLÓY, Á. (2019) Herding behaviour in an emerging market: Evidence from the Moscow Exchange. Emerging Markets Review, v. 38, p. 468487. DOI: $10.1016 /$ j.ememar.2018.12.002

IRSHAD, H.; TAIB, H. M. (2017) Calendar anomalies: Review of literature. Journal of Advances in Humanities and Social Sciences, v. 3, n. 6, p. 303-310. DOI: 10.20474/jahss3.6.2

KAPLANSKI, G.; LEVY, H. (2012) The holiday and yom kippur war sentiment effects: the Tel Aviv Stock Exchange (TASE). Quantitative Finance, v. 12, n. 8, p. 1283-1298. DOI: 10.1080/14697688.2010.504225

KHAN, K.; NASIR, M. A.; ROSSI, M. (2017) The calendar anomalies on performance and volatility of stock market: the effects of Ramadan on Karachi stock exchange. Global Business and Economics Review, v. 19, n. 1, p. 54-69. DOI: 10.1504/gber.2017.10000917

KREMER, S.; NAUTZ, D. (2013) Short-term Herding of Institutional Traders: New Evidence from the German Stock Market. European Financial Management, v. 19, n. 4, p. 730-746. DOI: 10.1111/j.1468-036X.2011.00607.x 
LAI, Y. W.; WINDAWATI, A. (2017) Risk, return, and liquidity during Ramadan: Evidence from Indonesian and Malaysian stock markets. Research in International Business and Finance, v. 42, p. 233-241. DOI: 10.1016/j.ribaf.2017.04.054

LITIMI, H.; BENSAÏDA, A.; BOURAOUI, O. (2016) Herding and excessive risk in the American stock market: A sectoral analysis. Research in International Business and Finance, v. 38, p. 6-21. DOI: 10.1016/j.ribaf.2016.03.008

MAHMUD, S. F.; TINIÇ, M. (2018) Herding in Chinese stock markets: a nonparametric approach. Empirical Economics, v. 55, n. 2, p. 679-711. DOI: 10.1007/s00181-017-1281-y

MAJEED, U.; RAHEMAN, A.; SOHAIL, M. K.; BHATTI, G. A.; ZULFIQAR, B. (2015) Islamic calendar events and stock market reaction: Evidence from Pakistan. Science International, v. 27, n. 3, p. 2559-2567. Available: http://www.sci-int.com/. Access: 24th June, 2019.

MARRETT, G. J.; WORTHINGTON, A. C. (2009) An empirical note on the holiday effect in the Australian stock market, 1996-2006. Applied Economics Letters, v. 16, n. 17, p. 1769-1772. DOI: 10.1080/13504850701675474

MEHRAN, J.; MEISAMI, A.; BUSENBARK, J. R. (2012) L'Chaim: Jewish holidays and stock market returns. Managerial Finance, v. 38, n. 7, p. 641-652. DOI: 10.1108/03074351211233104

NASARUDIN, A. F.; NOORDIN, B. A. A.; LAW, S. H; YAHYA, M. H. (2017) Investigation of herding behaviour in developed and developing countries: Does country governance factor matters? Capital Markets Review, v. 25, n. 2, p. 1-14. Available: https://www.mfa.com.my/. Access: 22th June, 2019.

NORVAISIENE, R.; STANKEVICIENE, J.; LAKSTUTIENE, A. (2015) Seasonality in the Baltic stock markets. Procedia-Social and Behavioral Sciences, v. 213, p. 468-473. DOI: 10.1016/j.sbspro.2015.11.435

OBAIDAT, A. (2016) The value relevance of accounting information in emerging stock exchange markets" case of Jordan. Research Journal of Finance and Accounting, v. 7, n. 12, p. 184-196. Available: https://iiste.org/Journals/index.php/RJFA. Access: 20th June, 2019.

QASIM, M.; HUSSAIN, R.; MEHBOOB, I.; ARSHAD, M. (2019) Impact of herding behavior and overconfidence bias on investors' decision-making in Pakistan. Accounting, v. 5, n. 2, p. 81-90. Available: http://www.growingscience.com/ac/ac.html. Access: 25th June, 2019.

RAHMAN, M. A.; CHOWDHURY, S. S. H.; SADIQUE, M. S. (2015) Herding where retail investors dominate trading: The case of Saudi Arabia. The Quarterly Review of Economics and Finance, v. 57, p. 46-60. DOI: 10.1016/j.qref.2015.01.002

RAMADAN, I. Z. (2015) Cross-Sectional absolute deviation approach for testing the herd behavior theory: The case of the ASE index. International Journal of Economics and Finance, v. 7, n. 3, p. 188-193. DOI: 10.5539/ijef.v7n3p188

ROSSI, M. (2015) The efficient market hypothesis and calendar anomalies: a literature review. International Journal of Managerial and Financial Accounting, v. 7, n. 3-4, p. 285-296.1 0. DOI: 10.1504/ijmfa.2015.074905

SALMAN IRAG AL-NAJAF, F. A.; SALEHI, M.; NIMR AL-MALIKI, H. S. (2018) The effect of Islamic sacred months on stock prices in Iran and Iraq Stock Exchanges. ISRA 
DOI: 10.14807/ijmp.v11i6.1146

International Journal of Islamic Finance, v. 10, n. 1, p. 111-119. DOI: 10.1108/IJIF-102017-0034

SEIF, M.; DOCHERTY, P.; SHAMSUDDIN, A. (2017) Seasonal anomalies in advanced emerging stock markets. The Quarterly Review of Economics and Finance, v. 66, p. 169181. DOI: 10.1016/j.qref.2017.02.009

SHAH, N.; QURESHI, M. N.; ASLAM, Y. (2017) An empirical investigation of Islamic calendar effect in global Islamic equity indices. International Journal of Economics and Finance, v. 9, n. 6, p. 57-68. DOI: 10.5539/ijef.v9n6p57

SHARMA, S. S.; NARAYAN, P. K. (2014) New evidence on turn-of-the-month effects. Journal of International Financial Markets, Institutions and Money, v. 29, p. 92-108. DOI: 10.1016/j.intfin.2013.12.002

SHARMA, S. S.; NARAYAN, P.; THURAISAMY, K. (2015) Time-varying herding behavior, global financial crisis, and the Chinese stock market. Review of Pacific Basin

Financial Markets and Policies, v. 18, n. 2, p. 1-31. DOI: 10.1142/S0219091515500095

SONJAYA, A. R.; WAHYUDI, I. (2016) The Ramadan effect: illusion or reality?. Arab Economic and Business Journal, v. 11, n. 1, p. 55-71. DOI: 10.1016/j.aebj.2016.03.001

TIME AND DATE. (2019) Muslim holidays. Available: https://www.timeanddate.com. Access: 23th June, 2019.

TRENCA, I.; PECE, A. M.; MIHUT, I. S. (2015) Herd behaviour of Institutional and individual investors in the context of economic governance: Evidence from Romanian stock market. Review of Economic Studies and Research Virgil Madgearu, v. 8, n. 1, p. 177190. Available: https://econ.ubbcluj.ro/rvm/en. Access: 22 June, 2019.

WASIUZZAMAN, S.; AL-MUSEHEL, N. A. (2018) Mood, religious experience and the Ramadan effect. International Journal of Emerging Markets, v. 13, n. 1, p. 290-307. DOI: 10.1108/IJoEM-01-2017-0001

YOUSAF, I.; ALI, S.; SHAH, S. Z. A. (2018) Herding behavior in Ramadan and financial crises: the case of the Pakistani stock market. Financial Innovation, v. 4, n. 1. DOI: 10.1186/s40854-018-0098-9 